\title{
RESEARCH METHODS OF CONFLICTS OF URBAN DEVELOPMENT IN HUMAN GEOGRAPHY
}

\author{
Artem MOZGOVYI \\ Institute of Geography, National Academy of Science of Ukraine, Kyiv, Ukraine \\ utor@ukr.net
}

\begin{abstract}
This article in the field of human geography is devoted to contradictions of urban development. Here is presented the characteristics of the main types of urban development and subjects of urban conflicts. In this article one can find meaning of terms "conflict activity" and "conflict potential" of urban envierment in human geography. Suggested the complex research methods of conflicts of urban development.
\end{abstract}

Key words: conflict, city, urban development, research methods, conflict activity, conflict potential.

UDC: 911.375 .3

\section{МЕТОДИЧНІ ЗАСАДИ СУСПІЛЬНО-ГЕОГРАФІЧНОГО ДОСЛІДЖЕННЯ КОНФЛІКТІВ МІСЬКОГО РОЗВИТКУ}

\author{
Артем МОзговиЙ \\ Інститут географії НАН України, м. Київ, Україна \\ utor@ukr.net
}

\begin{abstract}
Анотація: У статті розкрито суперечності міського розвитку з позицій суспільної географії. Наведено систематику міського розвитку і схарактеризовано основні його типи. Окреслено коло суб'єктів конфліктної взаємодії в місті. Розкрито суспільно-географічний зміст понять конфліктність і конфліктогенність міського середовища. Запропоновано методичний апарат дослідження конфліктів міського розвитку.
\end{abstract}

Ключові слова: конфлікт, місто, міський розвиток, методи дослідження, конфліктність, конфліктогенність.

удк: 911.375 .3

Вступ. Постановка проблеми. Онтологія конфлікту здавна цікавила фахівців різного профілю: у першу чергу філософів, а також психологів, соціологів, політологів, культурологів та представників багатьох інших гуманітарних галузей знань. Особливе місце у вивченні природи конфліктів посідають математичні вишукування, особливо в галузі теорії ігор. Певна розпорошеність та різнорідність наукового знання про природу конфліктів невипадково викликала потребу в його узагальненні та систематизації.

Отже, на певному етапі розвитку науки виникла потреба в розробці єдиного вчення про конфлікт. Першою спробою зробити це прийнято вважати працю американського вченого Кеннета Боулдінга «Конфлікт і захист: загальна теорія» [3], в якій він виклав основні положення своєї концепції «Загальної теорії конфлікту». На думку вченого, конфлікт - $є$ всезагальною й універсальною категорією, що має однакові етапи, функції та способи розв'язання незалежно від середовища та умов виникнення. Хоча цю ідею було запропоновано науковій громадськості ще півстоліття тому, змушені констатувати, що витворення «Загальної теорії конфлікту» не мало значних результатів і триває досі.

Дещо пізніше західних досліджень в галузі теорії конфліктів, проте в значній мірі незалежно від них, серед пострадянських наукових кіл набуває популярності міждисциплінарний напрям досліджень, що набув назви «конфліктологія».

(C) А. Мозговий
Цей термін не вживається західними науковцями i $€$ результатом витворчості в більшості своїй російських авторів. Можна припустити, що конфліктологія виникла в результаті наукових пошуків відповідей на виклики часів занепаду радянської системи - деволюційні рухи та численні етнополітичні конфлікти на теренах стагнуючої тоталітарної держави. Конфліктологія мала доволі поживний грунт для свого розвитку і пізніше - в пострадянських реаліях новоутворених незалежних держав як міждисциплінарний напрям дослідження конфліктів. Одначе, принагідно зауважимо, що досі не існує загальновизнаного уявлення про предмет конфліктології. У цій науковій розвідці ми спираємося на визначення Пірен М. І., за якою «конфліктологія це наука про зіткнення, проблемне функціонування особи, людського суспільства, природи, про взаємодію людини і природи» [8].

Аналіз останніх досліджень і публікацій. Для вітчизняної географії конфліктологічна проблематика, на відміну від західних географічних шкіл, є порівняно новою. Протягом останніх двох десятиліть на пострадянських просторах відбулося кілька наукових географічних форумів, котрі були присвячені теоретико-методологічним та прикладним аспектам наукового напряму, що набув назви «геоконфліктологія». Основну увагу при цьому було приділено географічним чинникам виникнення конфліктів, просторовій еволюції та організації конфліктів, типізації конфліктів 3 географічних позицій. Особливої актуальності на межі тисячоліть набули дослідження конфліктів, що розгортаються 
в суспільно-територіальних системах різного рангу.

Актуальність цього напряму географічних досліджень була неодноразово підтверджена в доповідях провідних географів під час Міжнародного географічного конгресу (ФРН, м. Кельн, 26-30 серпня 2012 р.), де тема ризиків і конфліктів у сучасному глобалізованому світі була винесена в ряд ключових [5].

Оцінюючи розвиненість географічних досліджень конфліктів за допомогою галузевонаукового підходу, стає очевидним, що найбільшого розвитку тема конфліктів набула в політичній географії та геополітиці, де вона активно опрацьовується протягом кількох десятиліть. Проте вивчення різних аспектів конфліктної взаємодії об’єктів у географічному середовищі представниками згаданих напрямків здійснюється, головним чином, на рівні значних територій та ареальних форм просторової організації, в той час як конфліктам в масштабах окремих поселень або їх груп, на нашу думку, не приділено належної уваги.

Географічне дослідження конфліктів не обмежується нині тільки областями політичної географії та геополітики. Усе більшою актуальності набувають дослідження конфліктів у галузі природокористування [7], вдосконалюються способи їх картографування [9]. Нині серед дослідників конфліктів найактуальнішою темою стали трагічні події на сході України [2; 4].

Формулювання цілей статті. Постановка завдання. Метою цієї наукової розвідки є висвітлення можливостей методичного апарату географії та суміжних наук в дослідженні конфліктів, а також порівняння ефективності різних методичних підходів при дослідженні конфліктів 3 позицій географічної науки.

Виклад основного матеріалу. У наукових уявленнях сьогодення розвиток складних систем, тобто відкритих й здатних до самоорганізації, не $\epsilon$ можливимбезсуперечностей,щойогосупроводжують i зумовлені структурною, функціональною та динамічною складністю цих утворень. Це цілковито стосується і територіальних систем як об’єкта географіï.

Так, структурна складність систем зумовлює «вертикальні» та «горизонтальні» суперечності між ієрархічно різними елементами; функціональна складність викликає суперечності, пов'язані з якісно різною, а іноді протилежною, спрямованістю процесів функціонування системи; динамічна складність породжує суперечності дисонансно-резонансного характеру, пов'язані 3 аритмічністю процесів, незбігом їхніх часових параметрів та несинхронізованістю взаємозалежних процесів. Найгострішими проявами таких суперечностей $є$ конфлікти.

У процесі накопичення й узагальнення людством наукового знання стає все більш очевидним, що концепти «розвиток» та «конфлікт» перебувають в діалектичній єдності. 3 одного боку, конфлікт позірно заперечує розвиток, а з іншого - виступає невід’ємним його атрибутом і навіть необхідною умовою. Серед усієї множини сучасних наукових визначень конфлікту найбільш прийнятним для умов нашого дослідження ми вважаємо наступне: конфлікт - це «протидія двох або більше суб'єктів, а іноді процесів, що претендують на зумовлюваний ними стан дійсності» [11].

Проблематика розвитку міського простору охоплює широке коло теоретичних i прикладних питань, дослідження котрих грунтується на таких концептах та базових наукових категоріях як «система», «розвиток» та «простір». Географічний зміст кожного 3 них виповнений множиною понять, термінів та причинно-наслідкових зв'язків. Географічні об'єкти як територіальні системи мають неабиякий потенціал розкриття змісту цих базових наукових категорій. Яскравим прикладом таких територіальних систем є місто.

Очевидним є те, що за своєю природою та характером функціонування місто має системний характер. Серед численних ознак складної системи в науковій літературі найчастіше згадуються відкритість такої системи, їі здатність до саморозвитку та самоорганізації. Усі ці риси притаманні системі міста: по-перше, місто завжди було і є відкритою системою, фактично «системою в системі» - в системі поселень; по-друге, будь-якому місту властиві саморозвиток й самоорганізація, так як саморозвиток закладено в самій сутності міста. Місто як «рушій прогресу» не можна уявити статичним, воно має розвиватись, розвиваючи прилеглі території. Саморозвиток конкретного міста зумовлюється як внутрішніми чинниками, так і зовнішніми впливами, котрі можна розглядати як прояви саморозвитку систем поселень, радше, систем розселення вищого рівня (регіональних, національних). Тому дуже важко дослідити процеси і визначити напрямки розвитку міста, чи навіть категорії міст, не врахувавши системності їх існування

Крім того, місто зі складними системами місто споріднює його структурна, функціональна та динамічна складність, що зумовлено значною концентрацією об'єктів, котрі взаємодіють на обмеженій території. Проте, на різних етапах розвитку суспільства характер взаємодії між об'єктами може бути різним. Динамізм функціонування міста зокрема проявляється: в рухах потоків населення 3 приміської зони до місць роботи вранці, і відтоці населення ввечері (маятникова міграція); в активному переміщенні власне міських жителів протягом дня, в пов'язаних 3 цим піках транспортної напруженості; в ритміці роботи виробництв та устаов, або в безперервності їх роботи; в цілодобовості життєзабезпечення міста (водо- та енергопостачання, сміттєвивезення та ін.). Розвиток міста, як наслідок динамізму функціонування, проявляється також у постійному будівництві, переплануванні вулиць, прокладанні нових комунікацій та адаптації міського середовища до нових умов в цілому.

Географія як наука-інтегратор має неабиякий методичний апарат для дослідження міської системи. Нині у вітчизняній суспільній географії в якості загального означення системних об'єктів най- 
частіше використовується поняття «суспільнотериторіальна система», що об'єднує виробничі, соціальні, населенські або природні елементи. При дослідженні окремих елементів суспільнотериторіальної системи на перший план виступають їхні функції. Подібні утворення мають свою систематику i, таким чином, конкретним типом суспільно-територіальних систем є міста.

Територія як просторова передумова цивілізаційних процесів $є$ базовою категорією географічної науки. Як природно-територіальні, так і суспільно-територіальні системи не можливі поза «місцем». Територіальність є однією 3 найважливіших ознак подібних утворень. Хоча сучасні міста переважно лишаються, радше, дискретною формою територіальної організації суспільства, однак вони теж складаються 3 окремих територіальних частин (підсистем), а також $є$ територіальними складовими масштабніших географічних об'єктів. Елементам суспільно-територіальної системи міста притаманні такі територіальні параметри, як різний ступінь доступності, територіальна конфігурація, територіальна концентрація та ін. Вочевидь, що згадані територіальні параметри істотно впливають на розвиток конкретного міського поселення.

Отже, спираючись на вищевикладене, спробуймо окреслити основні особливості міського розвитку. Виходячи 3 загальнонаукового сучасного уявлення про розвиток, під міським розвитком ми розуміємо незворотні, закономірні й спрямовані зміни суспільнотериторіальної організації міського простору. Цей процес супроводжується постійною трансформацією поселенської мережі 3 переміщенням населення в міста 3 істотною зміною способу його життя. Принагідно розглянемо більш ретельно кожну 3 питомих рис міського розвитку.

Так, незворотність змін характеризує функціонування міської системи, тобто циклічну i динамічну роботу функцій міста. Набір функцій міста, на нашу думку, відповідно до логіки розвитку, повинен проходити стадії від комплексу до системи. Наукове пояснення незворотності як риси міського розвитку має певні застереження. 3 історичної географії достеменно відомою $є$ маса прикладів «перетворення» міських поселень на сільські, тобто прикладів деградації міського середовища i це може свідчити, на перший погляд, про певну «зворотність» міського розвитку. Хибність такого пояснення полягає в тому, що перехід населеного пункту з категорії «міст» до категорії «сіл» свідчить, насправді, не про зворотність розвитку, а, навпаки, підтверджує його - розвитку - незворотність. Адже розвитку міста, як і будь-якої складної територіальної системи, $€$ властивою еволюційна стадійність: міста зароджуються, зростають, досягають розквіту, занепадають й, 3 рештою, зникають. Тобто перетворення міста на село є констатацією «смерті» міста. При цьому населений пункт «за інерцією» може ще деякий час зберігати за собою адміністративний статус міста, хоча його мешканці вже поколіннями ведуть руральний спосіб життя. Ця проблема - якісного розмежування міського i сільського середовищ - лишається ще доволі слабко розкритою в сучасній науці.

Друга питома риса міського розвитку спрямованість змін суспільно-територіальної системи міста визначає єдність розвитку міста, що надає йому рис внутрішньої взаємозалежності - траєкторії міського розвитку. Напрямок змін суспільно-територіальної системи міста, як правило, пов'язаний 3 ускладненням структури його господарства, збільшенням масштабів його економічного, соціального та екологічного впливу на прилеглу територію, появою нових елементів і функцій структури.

Саме в зв'язку 3 простеженням спрямованості розвитку певного міста найчастіше можна зіткнутись 3 оцінними судженнями окремих фахівців та громадськості щодо розвитку міста, йдеться про основні його тенденції - прогрес і регрес. Прогресивний розвиток міст, тобто напрям розвитку від «гіршого» до «кращого», досить тривалий історичний час був «наріжним каменем» міського управління й міської політики в Європі. Через європейський універсалізм загальна теорія прогресу і прогресивності міста була поширена на глобальному рівні. Проте з другої половини ХХ ст., коли негативні наслідки урбанізації, індустріалізації, технізації та інтернаціоналізації світового господарства стали очевидними, теорія прогресу стала піддаватись жорсткій критиці 3 боку громадськості. Нині «прогресивність» всього міського не $\epsilon$ вже такою беззаперечною.

Третя питома риса міського розвитку закономірність змін суспільно-територіальної системи міста передбачає суттєвий i постійно повторюваний взаємозв'язок елементів міської системи, визначальних етапів і форм процесу міського розвитку. Можна виділити загальні й одиничні, тобто універсальні та специфічні закономірності міського розвитку. Але це предмет окремого дослідження. Вважаємо, що закономірність є тією властивістю міського розвитку, що різнить його зі змінами катастрофічного характеру.

Очевидно, що навіть вичерпна характеристика окремих властивостей міського простору не створить наукової картини його розвитку. Вочевидь, процес міського розвитку має свою систематику, тобто певну видову структуру. При більш наближеному розгляді цього питання, ясно проступають, принаймні, чотири види міського розвитку, а саме: територіальний розвиток, демографічний розвиток, соціальноекономічний розвиток та функціональний розвиток.

Територіальний розвиток міста проявляється в територіальній експансії міської забудови і комунікацій на прилеглу місцевість. Якщо античне чи середньовічне міське середовище обмежувалось оборонними мурами й рідко «виплескувалось» за їхній периметр, то територіальне зростання сучасних міст $є$ безпрецедентним в людській історії. Згадаймо хоча б недавні зміни адміністративних меж Москви, коли площа цього міста зросла майже втричі.

Територіальна експансія міст $є$ часто невиправданою, особливо постсоціалістичних. 
Територіальний «прогрес» міста, особливо великого, завжди призводить до деградації прилеглої сільської місцевості та природного середовища. Вздовж основних транспортних магістралей, далеко за адміністративні межі сучасного великого міста розростаються «язики субурбанізації» - суцільно організована територія, колишня сільська місцевість, мешканці котрої ведуть урбаністичний спосіб життя й абсолютно відірвані від традиційного культурного субстрату села. Окремою проблемою територіального «прогресу» сучасних міст $є$ поширення так званих «котеджних містечок», яких тільки в передмістях сучасного Києва нараховується близько чотирьох десятків. Ці соціально замкнені «виплески капіталу» великого міста територіально віддалені від нього, але ще більше вони дистанційовані в інформаційному, культурному та ментальному відношеннях від середовища свого розташування. Фактично, йдеться про однобічний утилітарний зв'язок: споживацьке відношення й виснаження природних ресурсів сільської місцевості 3 боку мешканців такого містечка, а наслідками є відходи життєдіяльності, техногенне забруднення і сміття.

Демографічний «прогрес» міста проявляється, в першу чергу, в зростанні чисельності його населення. Оптимальної чисельності населення міста не існує, хоча не так давно науковцями робилися спроби іiі встановити. Очевидним є те, що число міських мешканців дуже швидко долає «раціонально встановлені» і «науково обгрунтовані межі», а геодемографічні процеси відбуваються за своїми законами. Хоча деяким державам вдається адміністративними методами регулювати чисельність міського населення (КНДР, КНР, колишній СРСР), проте це потребує встановлення тоталітарного політичного режиму i суперечить правам людини.

Негативними наслідками демографічного «прогресу» $є$ такі явища як псевдоурбанізація та прихована урбанізація. Суть котрих полягає в нерегульованій і неконтрольованій масовій міграції сільських мешканців до міст. Це населення прагне покращення якості життя, але не забезпечується в місті а ні належними умовами проживання, а ні гідною оплатою праці, а ні соціальним гарантіями. Це призводить до маргіналізації та криміналізації цілих районів і передмість, неінтегрованості й соціальної замкненості таких спільнот.

Таким чином, основна загроза територіального та демографічного «прогресу» міст полягає навіть не у вилучені нових земель, скажімо, із сільськогосподарського вжитку та зменшенні частки сільських мешканців певної території, а в скороченні простору витворення традиційної культури й припинення трансляції етнічних культурних кодів в колишній сільській місцевості, адже велике місто це культурний конгломерат, що не має етнічності.

«Прогресивний» соціально-економічний розвиток міста знаходить свій прояв в зростанні кількісних показників, що нерідко призводить до погіршення екологічних властивостей комплексів природи. Саме наслідки економічного і технічного прогресу призвели до глобальних проблем людства.

Прискорений соціально-економічний розвиток міст, порівняно 3 руральними просторами, найчастіше пов'язують 3 такою його властивістю як урбаністична концентрація. У свою чергу, урбаністична концентрація - це фундаментальна ознака міста, щ полягає в значній щільності різноманітних об'єктів і видів діяльності на обмеженій території.

Урбаністична концентрація характеризує місто як середовище життя людей і місце концентрації різноманітних, видів діяльності, що постійно диверсифікуються. Ці види життедіяльності знаходяться у постійному взаєморозвитку та взаємозалежності. 3 іншого боку, в близькому сусідстві знаходяться об'єкти, що нарізно тяжіють міста, але $\epsilon$ несумісними. Наприклад, перевантаження міського простору об'єктами промисловості, що завжди призводить до погіршення екологічної ситуації i, відповідно якості життя населення. Територіальна концентрація дає можливість отримати значний економічний ефект, проте нерозривно пов'язана 3 цілим рядом побічних негативних наслідки і факторами ризику для людини, серед яких: надмірна кількість мешканців і рівень концентрації населення, розміщення населення, яке підпадає під загрозу бути в зоні ураження, а також насиченість міста елементами техногенної інфраструктури.

На нашу думку, найбільш коректними індикаторами соціально-економічного «прогресу» міського розвитку є параметри якості життя містян. Саме через комплексне дослідження категорії якості життя населення розкриваються для розуміння такі поняття як спосіб життя, рівень життя та стиль життя мешканців населеного пункту. Динаміка якості життя мешканців є головним індикатором соціально-економічного розвитку міста i, одночасно, передумовою його перспективного розвитку, що зумовлює «привабливість» певного міста для праці та проживання.

Функціональний розвиток міста проявляється в перманентній трансформації його функціональної структури та розширенні спектру виконуваних функцій. Виходячи 3 цього, «прогрес» функціонального розвитку уявляється як розширення переліку виконуваних містом функцій, відповідно «регрес» - розвиток в бік монофункціональності.

Таким чином, приходимо до висновку, що прогрес в одному напрямі чи сфері обов'язково породжує конфлікти й регрес в інших сферах міського розвитку. Нині, як ніколи раніше, основні постулати теорії прогресу є хиткими, а впевненість в необхідності подальшого економічного й технологічного зростання є сумнівною. Усе більшої поширеності серед науковців набуває альтернативний теорії прогресу ймовірнісний підхід в розумінні цивілізаційного розвитку людства. Політику індустріалізації, урбанізації та прискореного розвитку великих міст заступила теорія меж зростання i, зрештою, концепція сталого збалансованого розвитку. Проте на шляху їі реалізації і впровадження існує немало об'єктивних і суб'єктивних перепон, 
подолання яких потребуватиме значних зусиль людської цивілізації.

До переліку основних функцій, що формують «обличчя» міста як територіального локусу людської культури найчастіше відносять наступні демографічну, виробничу, адміністративноуправлінську, комплексну соціальну функцію (вміщує культурно-освітню, охорони здоров'я, комунально-господарську та ін.), торговельну, транспортну та рекреаційну. Цей приблизний перелік міських функцій, на нашу думку, відображає основні сфери життєдіяльності містян та сутнісно розкриває особливості міського середовища - середовища цивілізаційного поступу. Кожна з міських функцій є багатоваріантною за формою та інтенсивністю свого прояву, одначе, в різних природних та суспільних умовах зміст їх лишається незмінним.

Якщо зануритись в аналіз функціонального розвитку міста глибше, з'ясується, що місту взагалі властива така фундаментальна риса як багатофункціональність. Міську багатофункціональність ми розуміємо не тільки у виробничому аспекті, а більш широко, охопивши всі види людської діяльності. Кожне, навіть найменше, місто з периферійного сільського району, що не має виробничої багатофункціональності та розвиненої інфраструктури, залишається втіленням багатофункціональності цілого району, що його оточує, виконуючи управлінські, торговельні, культурні, освітні та ін. функції.

Місто не може існувати без свого оточення. Воно пов'язане 3 ним, використовує ресурси оточуючого району, покликане обслуговувати цей район, а для цього його функціональна структура повинна бути розвиненою. Отже, багатофункціональність - це не просто ознака, це призначення міста.

Багатофункціональність дозволяє повніше використовувати елементи потенціалу міста: географічне положення, специфічне середовище, розвинену інфраструктуру, кваліфіковані кадри, виробничі фонди та ін. Але з іншого боку, розвиток функцій міста безпосередньо зумовлюється його потенціалом. Ця дивовижа є проявом примхливості саморозвитку міста i, власне, лежить в основі цього процесу.

Конфліктуючими сторонами в міській системі можуть виступати суб'єкти господарської діяльності, органи управління, суспільні групи, окремі особи і навіть технічні системи. Як зазначалось вище, міські конфлікти найчастіше виникають як результат загострення суперечностей розвитку міської системи. Конфліктувати між собою можуть навіть різні види розвитку міста, тобто територіальний, демографічний, функціональний та соціальноекономічний розвиток. До конфліктної ситуації також може призводити конкуренція між суб'єктами. Одначе, на нашу думку, не слід ототожнювати конкуренцію 3 конфліктом, т.я. сама по собі змагальність між суб'єктами за покращення умов функціонування в межах міського простору, за ресурси розвитку, чи досягнення певного стану дійсності не обов'язково призводить до конфлікту. Основними відмінними рисами конкуренції та конфлікту є те, що за конкуренції суб'єкти діють кожен «на своєму полі», а також те, що дії задля забезпечення успіху мають позитивний характер. Цікавим аспектом цього питання $є$ конкуренція між містами як економічними системами, або ж образами та брендами міст. Ця проблематика потребує окремого дослідження.

При характеристиці конфліктної взаємодії в міському просторі важливим $є$ розрізнення таких понять як конфліктна ситуація, конфліктність та конфліктогенність. Зупинимось на них більш ретельно.

Конфліктна ситуація - це збіг обставин, чи умов, що об'єктивно містить явні передумови для конфлікту i провокує деструктивні дії сторін, тобто виникнення конфлікту. Конфліктна ситуація $\epsilon$ передумовою реального конфлікту. Часто-густо iii асоціюють 3 власне конфліктом, що $є$ хибним уявленням, т.я. конфлікт може мати неявну, приховану, латентну фазу. Вона $є$ неявною для стороннього спостерігача, тому може лишитись непоміченою. Конфліктна ситуація в міському просторі сигналізує про нагальну необхідність втручання з боку муніципалітету. Конфліктам між приватними і громадськими інтересами містян, між різними міськими підсистемами завжди передує конфліктна ситуація. Розв'язання конфліктних ситуацій - показник ефективності міської влади.

У сучасній конфліктології одним 3 найбільш перспективних методів дослідження конфліктних ситуацій $є$ системно-ситуаційний аналіз [1]. За такого аналізу, саме конфліктна ситуація є основною одиницею дослідження, що має певні змістові й динамічні характеристики.

Однак, на наш погляд, найефективнішим методом виявлення i упередження конфліктних ситуацій міського розвитку $\epsilon$ їхній моніторинг, тобто метод чисельного аналізу конфлікту на основі низки контрольованих параметрів. Цей метод свого часу було вдало застосовано при аналізі реальних міждержавних конфліктів С.Ю. Закожурніковим [12]. Крім сигнальної функції моніторингу, формалізована система аналізу структури конфлікту має елементи експертної системи, надаючи користувачеві додаткову інформацію, засновану на досвіді вивчення загальних закономірностей розвитку. 3 метою підвищення достовірності методу чисельного аналізу, а також інтерпретації його результатів, його застосування доцільно поєднувати з формалізованою системою аналізу структури конфлікту, в якій чисельному аналізу відводиться сигнальна роль. Недоліком запропонованої системи моніторингу є слабка забезпеченість кількісної оцінки фіксацією якісних змін у структурі конфлікту. Основною складністю ефективності такої системи є діагностика основних параметрів тільки зароджується конфлікту. Об'єктивна складність виявлення подібних тенденцій пов'язана, по-перше, з тим, що конфліктогенні тенденції дуже часто виникають і розвиваються на тлі «інформаційного шуму», а по-друге, недостатньо чітко опрацьований механізм їхнього розпізнавання серед безлічі локальних суперечностей. 
У свою чергу, конфліктність - це показників, що характеризує частоту i гостроту виникнення i перебігу конфліктів в місті, ступінь залученості до конфліктної взаємодії суб’єктів. Виділяють низьку, середню, оптимальну i високу конфліктність. Центральною детермінантою конфліктності є система суперечностей, що виникають в процесі міського розвитку i відтворення предметного плану соціально-економічної активності. Рівень емерджентності в розвитку міста як системи, ступінь ефективності спільної діяльності суб'єктів міського середовища виступає провідним фактором, що визначає змістовні причини та інтенсивність конфліктності в місті. На прикладі дослідження інших складних систем конфліктологами було помічено, що деякий рівень конфліктності не є фактором дезінтеграції високоефективної системи спільної діяльності. Такий рівень конфліктності є оптимальним для функціонування системи.

Враховуючи вищевикладене, на цьому етапі дослідження, під конфліктогенністю міського розвитку ми пропонуємо розуміти потенціал можливих конфліктів, що виникатимуть в процесі взаємодії суб'єктів міського розвитку, що може впливати на стан міського середовища та проявляється у мобілізації просторових, матеріальних i нематеріальних ресурсів, асиметричність деструктивних дій та може призвести до згубних наслідків для сторін-носіїв інтересів. Конфліктогенність характеризує потенціал конфліктної взаємодії на території: міста в цілому, окремого району, зони впливу міста.

Окремою проблемою в дослідженні конфліктів міського розвитку є питання про їхню систематику. У сучасній науковій практиці систематизації конфліктів існує множина підходів. Це зумовлено доволі широким колом наук і галузей знань, що вивчають конфлікти - від психології до теорії міжнародних відносин. Проаналізувавши і порівнявши існуючі класифікації конфліктів, запропоновані представниками різних наук, ми дійшли висновку, що для потреб географічного дослідження конфліктів можуть бути використані далеко не всі з них.

Переходячи від загальних питань міського розвитку до національного рівня дослідження, зауважимо, що Україна є сьогодні високоурбанізованою країною. Хоча за офіційними даними в міських поселеннях нашої країни проживає майже 69\% населення (на 01.01.2014р.), цей показник не відображає реальних наслідків урбанізації, тому що спирається на формальну ознаку адміністративної реєстрації місця проживання громадян. За нашими оцінками, рівень урбанізованості України давно вже досяг 75\%, тобто фактично країна за цим показником знаходиться в числі найбільш урбанізованих націй світу. Природно, що і всі проблеми і негативні наслідки урбанізації мають гострий прояв в Україні.

Нині в Україні нараховується 460 міст (на 01.01.2015 р.), з них лише 45 відносять до великих, тобто таких, що мають чисельність населення понад 100 тис. осіб. Географічно більшість 3 їх числа розташована на сході та півдні країни. Ця група міст вирізняється серед інших найвищим рівнем соціально-економічного розвитку, проте, водночас, великім містам притаманна найбільша внутрішньогрупова строкатість за якістю міського середовища. На тлі великих міст України за соціально-економічними умовами розвитку чітко контрастують міста-мільйонники (в значенні статусу, а не кількісної характеристики) та обласні центри. Саме в них спостерігається найвища подієва активність в нашій країні. Саме в них ухвалюються рішення щодо напрямів розвитку території держави. 3 рештою, саме в них найчастіше відбувається зіткнення інтересів, як приватних і суспільних, так місцевих і національних.

Принагідно зауважимо, що, на нашу думку, показник питомої частки міського населення в Україні та деяких інших пострадянських країнах не відбиває реальних результатів урбанізації в цих державах. Адже до міського населення тут зараховують і мешканців т.зв. «селищ», відповідно до Конституції України, в минулому - «селищ міського типу». Відомо, що ця категорія міських поселень була запроваджена комуністичною владою в процесі адміністративно-територіальної реформи 1923-1929 рр. 3 метою штучного підвищення рівня урбанізованості населення. Саме тому ми вважаємо за недоцільне існування такої категорії поселень, вона має бути скасована в процесі майбутньої адміністративно-територіальної реформи, як це вже було зроблено в Польщі, країнах Балтії та Молдові.

На наш погляд, в основі обліку міського населення країни має лежати не штучний підхід адміністративного «затягування» населених пунктів до категорії «міських», а визначення числа мешканців урбанізованих територій. На цьому етапі дослідження, під урбанізованою територією ми розуміємо місцевості, незалежно від адміністративних меж (як міські, так і сільські), переважна більшість мешканців яких ведуть урбаністичний спосіб життя.

Міський (урбаністичний) спосіб життя ми розуміємо як історично сформовану соціокультурну підсистему міського устрою, основною функцією якої є організація процесу життєдіяльності соціальних суб'єктів в умовах специфічної соціопросторової реальності міста. Важливо розуміти, що поряд 3 окремими індивідами, суб'єктами міського способу життя виступають демографічні, культурні, професійні та інші спільноти. Особливості способу життя цих спільнот $є$ наслідком різних умов життєдіяльності людей, що належать до цих груп. 3 одного боку, феномен міського способу життя - це наслідок процесу урбанізації, що є способом організації життя індивідів і соціальних груп, котрий дозволяє їм співіснувати, взаємодіяти і розвиватися в урбаністичному соціально-просторовому середовищі 3 високим рівнем соціосуб'єктної, матеріально-предметної та інформаційної щільності. 3 іншого боку, міський спосіб життя це комплексна характеристика, що дозволяє синтезувати кількісні та якісні показники, котрі висвітлюють різні сторони життя містян. 
Урбаністичний спосіб життя можна схарактеризувати засобами показників рівня та якості життя. Так, рівень життя, що характеризуе ступінь задоволення різних потреб індивіда, як правило, виражається в кількісному вимірі, наприклад, у грошових одиницях. У свою чергу, якість життя являє комплексну характеристику, що включає всю палітру матеріальних і нематеріальних цінностей. Ця характеристика відображається в оцінці соціальної якості умов життєдіяльності та можливостей використання цих умов для реалізації та відтворення найважливіших потреб індивіда.

Традиційно в науці виділяють три компоненти міського способу життя: об'єктивні умови життєдіяльності, власне форми життєдіяльності i суспільна свідомість міських жителів. Взаємозв'язок цих компонентів полягає в тому, що, 3 одного боку, об'єктивні умови життєдіяльності суб'єктів міського способу життя визначають відповідні їм форми життєдіяльності, і ці форми знаходять своє відображення в суспільній свідомості міських мешканців. 3 іншого боку, зміни, що відбуваються в суспільній свідомості під культурними, релігійними чи ідеологічними впливами, є чинником змін форм життєдіяльності суб'єктів міського способу життя, що неминуче призводить до зміни самих об'єктивних умов життєдіяльності. При такому методологічному підході урбаністичний спосіб життя постає як динамічна система, що функціонує в межах міського устрою. Тому суспільно-географічні дослідження феномена міського способу життя могли б бути надзвичайно корисними для формування завдань планування міського розвитку.

Враховуючи вищевикладене, вважаємо, що в основу обліку числа міських мешканців країни необхідно покласти не «міську реєстрацію», а спосіб життя населення. У такому разі природно виникає питання про критерії «міського» та «сільського» способів життя для потреб обліку. Лише зазначимо, що світова практика й вітчизняна наука вже мають помітний доробок в цій царині. Вважаємо можливим, запровадити такий «якісний» статистичний облік міського населення вже при найближчому Всеукраїнському переписі населення.

Національна статистика не передбачає збору та опрацювання даних щодо конфліктів, а, між тим, параметризація й формалізація процесів конфліктної взаємодії $\epsilon$ першочерговим завданням в межах географічного дослідження конфліктів. Існуюча статистика, що відображає криміногенну ситуацію в населених пунктах розкриває конфліктність лише частково, і переважно стосується міжособистісних конфліктів. Добір кількісних показників просторового розвитку, що представлені в національній системі статистики України, на нашу думку, неодмінно призведе до «ефекту Уробороса». Тобто намагання виявити серед статистичних показників передумови того чи іншого конфлікту, призводитимуть до «препарування» його наслідків, т.я. неможливо досліджувати динамічне явище в статичних умовах.

На наш погляд, для потреб конкретного географічного дослідження конфліктів на певній території $\epsilon$ можливим використання наступних методів: методу контент-аналізу - для збору первинної інформації; методу ранжування - для систематизації зібраної кількісної інформації; методу івент-аналізу - для корекції та валідизації отриманих результатів. Також особливого значення при дослідженні конфліктів набувають давні географічні методи, такі як описово-географічний, історикогеографічний та порівняльно-географічний.

Висновки і перспективи подальших розвідок. У результаті цієї короткої наукової розвідки можемо зробити наступні висновки і узагальнення:

При дослідженні конфліктної взаємодії на конкретній території доволі ефективними виявляються класичні спеціальногеографічні методи: описово-географічний, порівняльногеографічний та історико-географічний. Зумовлено це тим, що, по-перше, конфлікт як явище в сучасній науці має вже усталену схему опису, котру видається можливим адаптувати до потреб географії. По-друге, акумульована база описів конфліктів на конкретній території створює широке поле для компаративістики. Стають можливими не тільки порівняння конфліктів, що відбуваються в межах різних територіальних систем, а порівняння різночасових конфліктів.

Використання методу районування при дослідженні конфліктів матиме певні особливості, т.я. при дослідженні конфліктів використання категорій спеціалізації території, наявності центру, а також виділення меж районів матиме, на нашу думку, методологічні обмеження. Більш прийнятним для потреб географічного дослідження конфліктів нам видається зонування території за кількісними і якісними характеристиками конфліктів.

Також можемо виснувати, що картографічний метод дослідження конфліктної взаємодії на території дозволяє відобразити: ареали поширення конфліктів різного типу на певній території, ступінь конфліктності, динаміку перебігу того чи іншого конфлікту. У цьому контексті, особливо цінним для нас є досвід історичної науки, а саме - створення історичних карт конфліктів.

Проте необхідно враховувати, що при безоглядному використанні географічних методів в дослідженнях конфліктів створюється загроза редукціонізму. Спрощений погляд на конфлікт як систему може загрожувати науковою некоректністю отриманих результатів. На нашу думку, географічне дослідження конфліктів потребує широкого залучення методів суміжних галузей знань та інших наук. За умов відсутності в національній статистичній системі даних, що безпосередньо, або ж опосередковано характеризували б конфліктність в населених пунктах та за ї межами, збір даних для потреб дослідження, на нашу думку, має грунтуватись на івент- та контент-аналізі, системноситуативному аналізу та групі інших соціологічних методів дослідження конфліктної взаємодії. 


\section{References:} Russian)

1. Ancupov A.Â. Šipilov A.I. Slovar' konfliktologa [Conflictologist's dictionary]. Moscow, 2010 , 656 p. (In

2. Aslanov S. Etnopolìtičnij konflìkt (gìbridna vìjna na Shodì Ukraïni) âk naslìdok regìonal'noï etnonacìonal'noï politiki [Ethnopolitical conflict (hybrid war in Eastern Ukraine) as a consequence of a regional ethnic policy]. Viče. Žurnal Verhovnoï Radi Ukraïni [Viche. Journal of the Verkhovna Rada of Ukraine], 2015, N. 14. Access mode: http:// www.viche.info/ journal/4822/ (In Ukrainian).

3. Boulding K. E. Conflict and defense: a general theory. New York: Harper \& Brothers, 1962, 349 p.

4. Dodonov R. Kriza, vìjna či konflìkt - âk korektno nazivati podii na Shodì Ukraïni? [Crisis, war, or conflict: what is a correct name for the events in Eastern Ukraine?]. Shìd. Analitiko-informacijnij žurnal [The East. Analytical and information magazine], 2015, Vol. 2 (134), pp. 107-112. (In Ukrainian).

5. IGC COLOGNE 2012 - 32nd International Geographical Congress Cologne (26-30 August 2012). Access mode: http://igc2012.org/frontend/index.php 449 p.

6. Ley D. A Social Geography of the City. Harper \& Row Series in Geography. New York: Harper \& Row, 1983,

7. Petrušenko M. M. Ocìnka ekologo-ekonomičnih konflìktìv ìz urahuvannâm činnika bezpeki [Assessment of ecological and economic conflicts with regard to safety]. Regional'na ekonomika [Regional economy], 2012, Vol. 4, pp. 115-122. (In Ukrainian).

8. Pìren M. Ì. Konfliktologiâ: Pidručnik [Conflictology: Textbook]. Kyiv, 2003, 360 p. (In Ukrainian).

9. Švec' O. B. Geografičnij zmìst vivčennâ socìokul'turnih konfliktìv [The geographic content of the study of social-cultural conflicts]. Ukraïns’kij geografičnij žurnal [Ukrainian Geographical Journal], 2011, Vol. 3, pp. 52-56. (In Ukrainian).

10. Topčiêv O. G. Suspil'no-geografičnì doslidžennâ: metodologîa, metodi, metodiki [Researchs in human geography: methodology, methods, techniques]. Odessa, 2005, 632 p. (In Ukrainian). Russian).

11. Vsemirnaâ ènciklopediâ. Filosofiâ [The world encyclopedia. Philosophy]. Moscow, 2001, 1312 p. (In

12. Zakožurnikov S. Û. Analiz Folklendskogo konflikta [The analysis of the Falklands conflict]. Rabočie tetradi [Workbooks], Diplomatic Academy of the MFA of Russia, 1992, Vol. 6, pp. 49-56. (In Russian). 